\title{
KOMPOSISI JENIS, PENYEBARAN, DAN KEPADATAN STOK IKAN DEMERSAL LAUT DALAM DI PERAIRAN SAMUDERA HINDIA SELATAN JAWA DAN BARAT SUMATERA
}

\author{
Ali Suman"), Budi Iskandar Prisantoso'), Fayakun Satria1), dan Enjah Rahmat ${ }^{2)}$ \\ 1) Peneliti pada Pusat Riset Perikanan Tangkap, Ancol-Jakarta \\ 2) Teknisi Litkayasa pada Balai Riset Perikanan Laut, Muara Baru-Jakarta
}

\begin{abstract}
ABSTRAK
Penelitian bertujuan untuk mengkaji komposisi jenis, penyebaran, dan kepadatan stok ikan demersal laut di perairan ZEEI selatan Jawa dan barat Sumatera. Data yang dianalisis merupakan hasil survei yang dilakukan bulan September sampai dengan Oktober 2004 dengan menggunakan K.M. Baruna Jaya IV. Estimasi kepadatan stok dilakukan dengan menggunakan metode sapuan dengan pengambilan contoh acak bertingkat. Hasil penelitian menunjukkan bahwa komposisi jenis ikan demersal laut dalam di perairan selatan Jawa terdiri atas 169 spesies ikan, 31 spesies krustasea, dan 20 spesies Chepalopoda. Komposisi hasil tangkapan ikan didominasi oleh ikan ashiro (Lamprogrammus niger) sekitar $45 \%$ dan ikan layur (Trichiurus lepturus) sekitar $22 \%$. Di perairan barat Sumatera ditemukan komposisi jenis hasil tangkapan meliputi 281 spesies ikan, 42 spesies krustasea, dan beberapa spesies Chepalopoda serta jenis yang dominan adalah ikan ashiro (Lamprogrammus niger) sekitar $20 \%$ dan Hoplosthethus sp. sekitar $17 \%$. Jenis ikan demersal laut dalam yang memiliki penyebaran paling luas adalah Chlorophtalmus nigromarginatus di perairan selatan Jawa dan Diretmoides pauciradiatus di perairan barat Sumatera. Kelimpahan stok ikan demersal laut dalam tertinggi ditemui pada kedalaman 700 sampai dengan $1.100 \mathrm{~m}$ dan terendah didapatkan pada kedalaman 200 sampai dengan $400 \mathrm{~m}$. Kepadatan stok ikan demersal laut dalam berkisar antara 0,8 sampai dengan 39,9 ton $\mathrm{km}^{-2} \mathrm{di}$ perairan selatan Jawa dan berkisar 0,2 sampai dengan 7,4 ton $\mathrm{km}^{-2}$ di perairan barat Sumatera.
\end{abstract}

KATA KUNCI: jenis kompisisi, penyebaran, kepadatan stok, ikan demersal laut dalam, Samudera Hindia

\section{ABSTRACT: Species composition, distribution, and stock density of deep sea demersal fish in the southern Java and western Sumatera of the Indian Ocean. By: Ali Suman, Fayakun Satria, and Enjah Rahmat}

The objective of this research is to study species composition, distribution, and stock density of deep sea demersal fish in the southern Java and western Sumatera of the Indian Ocean EEZ waters. The study was done based on the data collected from the survey conducted between September and October 2004 using Baruna Jaya IV research vessel. The study was basically conducted by applying swept area method with stratified random sampling. The results show that the species composition of deep sea demersal in southern off Java waters consisted of 169 in fishes, 31 in crustaceans, and 20 in chephalopods. The catch of deep sea demersal fish was dominated by ashiro (Lamprogrammus niger) about $45 \%$ and hair tail (Trichiurus lepturus) about 22\%. Species composition of deep sea demersal fish in west off Sumatera waters consisted of 281 species of fishes, 42 species in crustaceans and some types of chepalopods. The dominant species was Lamprogrammus niger (ashiro) with about $20 \%$ of the total catch and Hoplosthethus sp. with about $17 \%$ of the total catch. The widest species distribution of is resource was Chlorophtalmus nigromarginatus in southern off Java waters and Diretmoides pauciradiatus in western off Sumatera waters. The highest abundances of deep sea resources were caught at the depth of 700 to $1,100 \mathrm{~m}$ and the lowest at the depth of 200 to $400 \mathrm{~m}$. Stock density in southern off Java waters was 0.8 to 39.9 ton $\mathrm{km}^{-2}$ and about 0.2 to 7.4 ton $\mathrm{km}^{-2}$ in western off Sumatera waters.

KEYWORDS: $\quad$ species composition, distribution, stock density, deep sea demersal fish, Indian Ocean

\section{PENDAHULUAN}

Produksi ikan demersal di Indonesia sebagian besar berasal dari usaha perikanan skala kecil. Pada umumnya daerah penangkapan ikan tersebut terbatas di perairan pantai atau perairan dangkal yang merupakan daerah paparan benua dengan kedalaman yang kurang dari $100 \mathrm{~m}$. Menurut Naamin (1987), perairan yang mempunyai kedalaman kurang dari 100 $\mathrm{m}$ tersebut hanya sekitar 1,7 juta $\mathrm{km}^{2}$ atau sekitar $50 \%$ dari daerah teritorial Indonesia. Peningkatan armada penangkapan setiap tahun pada daerah penangkapan yang terbatas tersebut mengakibatkan tingkat pemanfaatan sumber daya ikan demersal di perairan Indonesia sudah berada dalam tahapan yang sudah jenuh (Anonimus, 2005). Melihat status pemanfaatan

Kosrespondensi penulis:

JI. Pasir Putih I, Ancol Timur-Jakarta 14430, Telp. (021) 64711940, Fax. (021) 6402640, E-mail: rccf_office@indo.net.id 
ikan demersal tersebut, maka dalam jangka panjang akan berdampak pada terjadi degradasi stok dan selanjutnya akan mengancam kesinambungan pemanfaatan sumber daya. Untuk mengantisipasi hal tersebut, maka perlu dilakukan pengembangan pemanfaatan daerah penangkapan dengan mencari potensi baru sumber daya ikan demersal di perairan Indonesia.

Dalam kaitan tersebut, maka dilakukan kerja sama penelitian antara pemerintah Indonesia (Departemen Kelautan dan Perikanan) dan Jepang (Overseas Fishery Coorperation Foundation) untuk mengkaji stok ikan demersal laut dalam yang diharapkan sebagai potensi baru pengembangan sumber daya ikan demersal di Indonesia. Informasi mengenai sumber daya ikan demersal laut dalam di perairan Indonesia sangat terbatas dan sampai dengan saat ini beberapa penelitian yang telah dilakukan adalah ekspedisi KARUBAR yang bertujuan untuk mengetahui stok ikan demersal laut dalam di perairan sekitar Kepulauan Kai, Aru, dan Tanimbar (Soselisa et al., 1993) dan ekspedisi Umitaka Maru (Sondita et al., 2004). Penelitian lain dengan kapal Korea OH DAE SAN mengatakan tertangkap jenis Solenocera prominentis pada kedalaman $200 \mathrm{~m}$ di sebelah selatan Jawa (Anonimus, 1972) serta ditemukan udang penaeid laut dalam di perairan Bali,
Laut Flores, Selat Makassar, Laut Banda, dan Laut Arafura (George, 1967).

Tulisan ini akan membahas komposisi jenis, penyebaran, dan kepadatan stok ikan demersal laut dalam di perairan Samudera Hindia sebelah barat Sumatera dan selatan Jawa yang diharapkan dapat dijadikan sebagai bahan masukan untuk tujuan pengembangan sumber daya ini serta dasar bagi pengkajian selanjutnya.

\section{BAHAN DAN METODE}

Data dan informasi yang diperoleh merupakan sebagian dari hasil kerja sama penelitian yang dilakukan antara pemerintah Indonesia dan Overseas Fishery Coorperation Foundation Jepang. Pelayaran penelitian dilaksanakan pada bulan September sampai dengan Oktober 2004. Wilayah perairan yang menjadi lokasi penelitian adalah perairan Samudera Hindia sebelah barat Sumatera di luar perairan teritorial Indonesia dengan kedalaman antara 200 sampai dengan 1.100 m (Gambar 1 dan 2). Pengambilan contoh dilakukan secara acak bertingkat yaitu wilayah survei dibagi berdasarkan pada strata kedalaman dan selanjutnya pada tiap-tiap kedalaman tersebut diambil contoh secara acak.

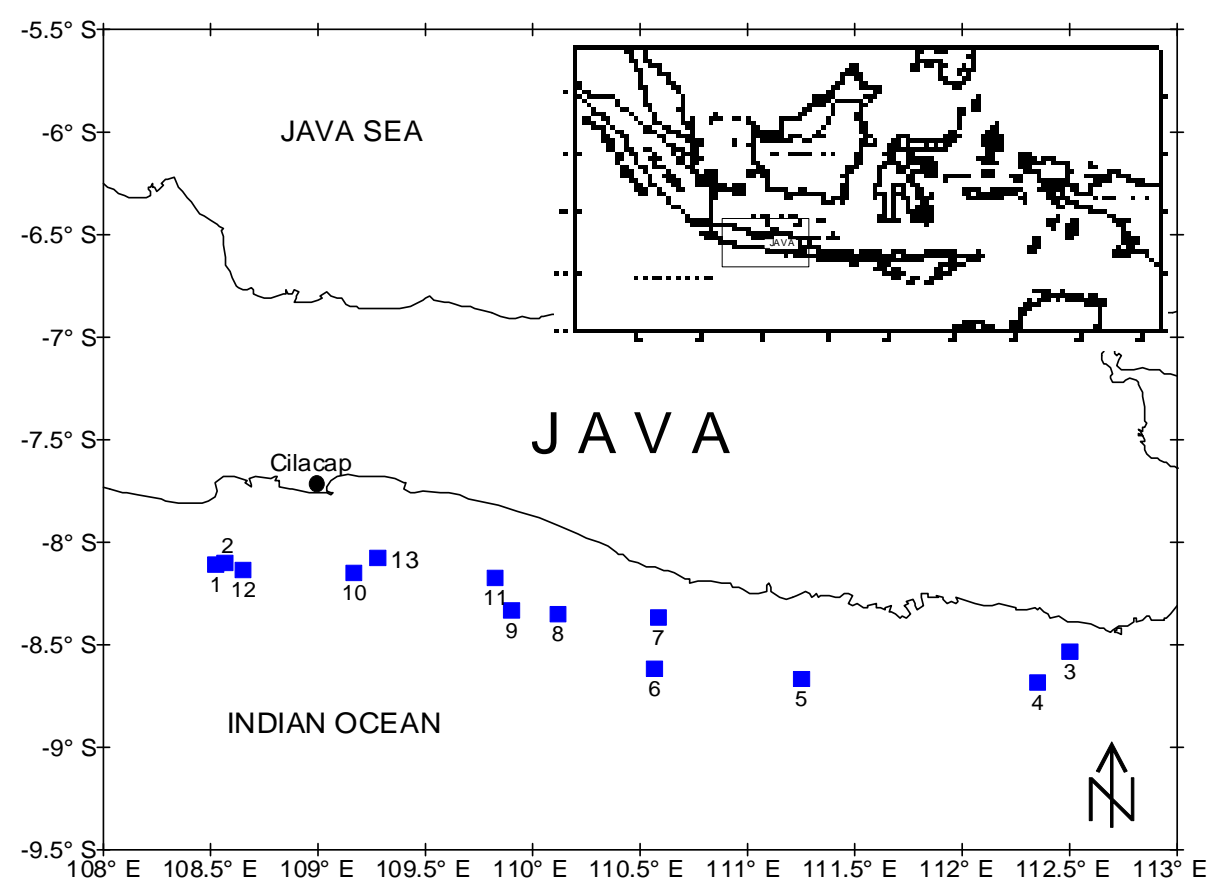

Gambar 1. Posisi stasiun trawl di perairan Samudera Hindia sebelah selatan Jawa.

Figure 1. Sampling site in south Java of Indian Ocean. 


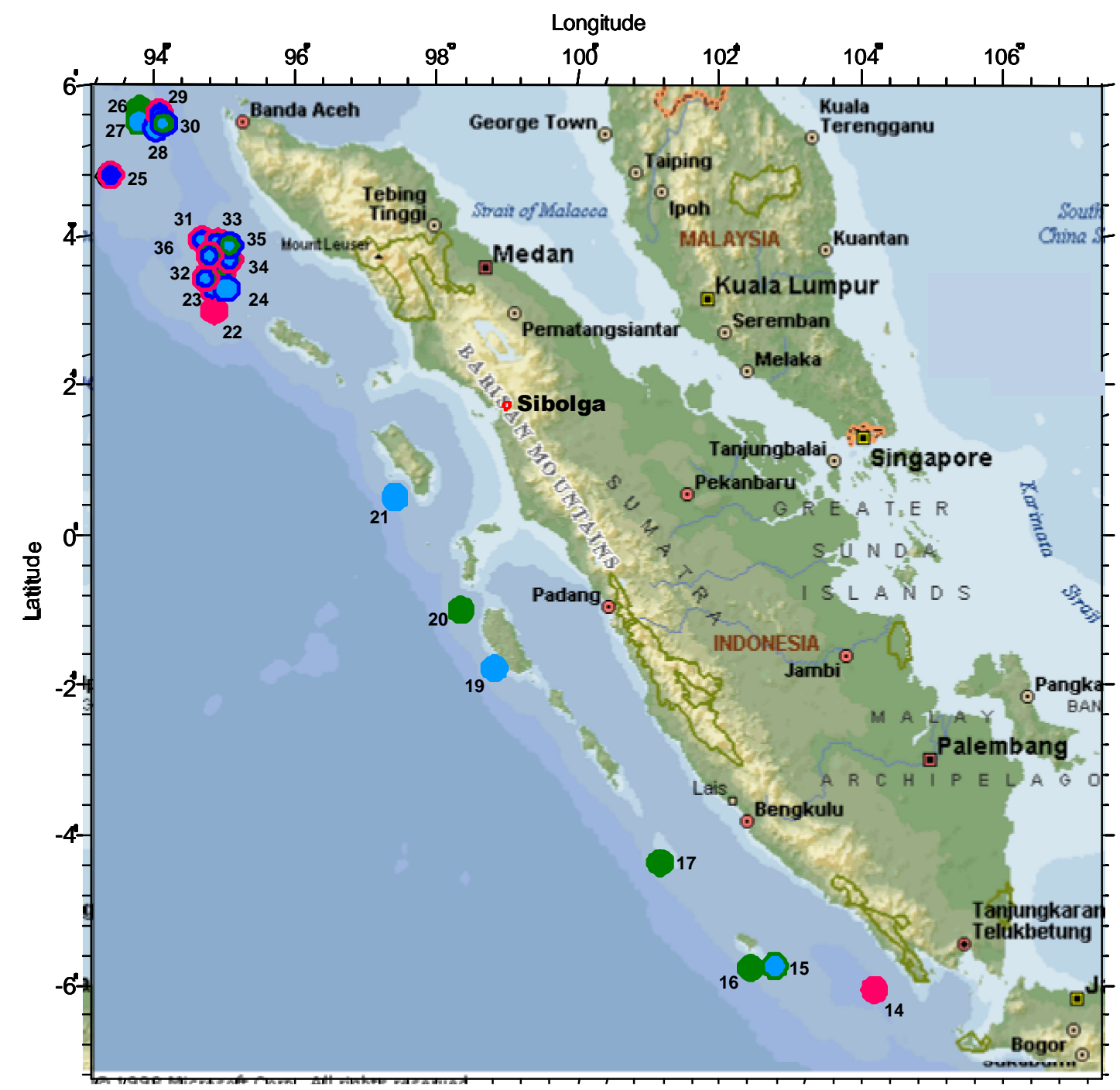

Gambar 2.

Posisi stasiun trawl di perairan Samudera Hindia sebelah barat Sumatera.

Figure 2.

Sampling site in western Sumatera of Indian Ocean.

Pelayaran penelitian dilaksanakan dengan kapal penelitian Baruna Jaya IV (1.219 GT) dengan alat tangkap trawl. Panjang head rope dari jaring trawlyang digunakan adalah 31,6 m (Anonymous, 2005). Identifikasi jenis sumber daya ikan demersal laut dalam digunakan buku King (1986); Dall et al. (1990); Holthuis (1991); Carpenter \& Niem (1998); Nakabo (2002). Pendugaan kepadatan stok dilakukan melalui perhitungan sebagai berikut (Shindo, 1973; Saeger et al., 1976; Sparre \& Venema, 1992, Anonymous, 2005a) yaitu:

Luas daerah yang disapu trawl adalah:

$\mathrm{a}=\mathrm{V} \cdot \mathrm{t} \cdot \mathrm{h} \cdot \mathrm{X}^{2}$ di mana:

$\mathrm{a}=$ luas daerah yang disapu trawl

$\mathrm{V}=$ kecepatan kapal selama penarikan (3 knot)

$\mathrm{t}=$ waktu yang diperlukan selama towing $(0,5 \mathrm{jam})$

$\mathrm{h}=$ panjang tali ris atas (head rope)

$\mathrm{X}^{2}=$ konstanta

Kepadatan stok:

$\mathrm{Q}=\mathrm{Cw} / \mathrm{a}\left(\mathrm{kg} \mathrm{km}^{-2}\right)$

di mana:

$\mathrm{Cw}$ = laju tangkap

a = luas sapuan 


\section{HASIL DAN BAHASAN}

\section{Komposisi Jenis}

Dari hasil penelitian menunjukkan bahwa ikan demersal laut dalam yang tertangkap di perairan selatan Jawa terdiri atas 169 spesies 31 spesies Crustasea dan 20 jenis Chepalopoda. Komposisi hasil tangkapan didominasi oleh ikan ashiro (Lamprogrammus niger) sekitar $45 \%$ dan ikan layur sekitar 22\% (Tabel 1). Di perairan barat Sumatera terlihat ikan demersal laut dalam yang tertangkap meliputi 281 spesies ikan, 42 jenis krustasea, dan beberapa tipe Chepalopoda. Hampir sama dengan di perairan selatan Jawa terlihat komposisi jenis ikan demersal laut dalam yang tertangkap di perairan barat Sumatera didominasi oleh ikan ashiro (Lamprogrammus niger) sekitar $20 \%$ dan Hoplosthethus sp. sekitar 17\% (Tabel 1).

Tabel 1. Komposisi jenis ikan demersal laut dalam di perairan selatan Jawa dan barat Sumatera Table 1. Catch composition of major species of fishes in southern Java and western Sumatera waters

\begin{tabular}{llccc}
\hline \multirow{2}{*}{ Lokasi/Location } & \multicolumn{1}{c}{ Jenis/Species } & Kasil tangkapan/Catch & $\begin{array}{c}\text { Frekuensi kejadian/ } \\
\text { Occurrence } \\
\text { (\%) }\end{array}$ \\
\cline { 3 - 5 } & & 2.348 & $\begin{array}{c}\text { Total } \\
\%\end{array}$ & $\begin{array}{c}17 \\
\text { Perairan ZEE }\end{array}$ \\
\cline { 3 - 5 } selatan Jawa & Lamprogrammus niger & 1.161 & 22 & 33 \\
& Trichiurus lepturus & 140 & 3 & 50 \\
& Squalops megalops & 59 & 1 & 50 \\
& Chlorophtalmus nigromarginatus & 1.468 & 29 & - \\
Perairan ZEE & Jenis lain (165 spesies) & 247 & 20 & 43 \\
barat Sumatera & Lamprogrammus niger & 209 & 17 & 52 \\
& Hoplosthethus sp. & 55 & 5 & 65 \\
& Diretmoides pauciradiatus & 45 & 4 & 35 \\
& Beryx splendens & 652 & 54 & - \\
\hline
\end{tabular}

Dari komposisi hasil tangkapan pada Tabel 1 terlihat bahwa jenis yang mendominasi di perairan selatan Jawa berupa ikan layur (Trichiurus lepturus) dan cucut (Squalops megalops) yang juga merupakan ikan ekonomis penting dan sudah diusahakan di Indonesia. Komposisi jenis yang berlainan ditemukan di perairan barat Sumatera dengan ditemukan jenis ikan demersal laut dalam yang dominan berupa ikan ekonomis penting yaitu Hoplosthethus sp. dan Beryx splendens (Anonymous, 2006). Ada perbedaan komposisi jenis hasil tangkapan antara perairan selatan Jawa dan barat Sumatera diduga karena ada perbedaan dasar perairan sebagai habitat ikan demersal. Di perairan selatan Jawa dasar perairan adalah datar dan cenderung berlumpur sehingga merupakan habitat utama ikan Lamprogrammus niger (ashiro), Trichiurus lepturus, Squalops megalops, dan Chlorophtalmus nigromarginatus. Sementara itu, di perairan barat Sumatera dasar perairan adalah keras dan cenderung bergunung-gunung (Wudianto \& Satria, 2007) dan kondisi yang demikian merupakan habitat yang disukai ikan Lamprogrammus niger (ashiro), Hoplosthethus sp. Diretmoides pauciradiatus, dan Beryx splendens. Dalam hal ini, terdapat suatu pengecualian terhadap ikan ashiro yang terlihat dapat beradaptasi terhadap ke-2 tipe dasar perairan tersebut. Penelitian di perairan dalam Kai, Tanimbar, dan Laut Timor telah menemukan jenis-jenis ikan demersal laut dalam sekitar 180 spesies dan yang mendominasi hasil tangkapan sekitar adalah ikan famili Myctophidae (Soselisa et al., 1993). Hasil ekspedisi Umitaka Maru di perairan selatan Jawa juga telah menemukan 115 spesies ikan demersal laut dalam dan yang mendominasi adalah ikan pari (famili Plesiobatididae) (Sondita et al., 2004).

Selanjutnya, pengukuran frekuensi panjang ikan demersal laut dalam yang dilakukan terhadap ikan yang dominan tertangkap di perairan selatan Jawa adalah sebagai berikut 1) ikan Lamprogrammus niger (ashiro) memiliki kisaran panjang antara 29,5 sampai dengan $64,5 \mathrm{~cm}$ (TL); 2) ikan layur (Trichiurus lepturus) berkisar antara 64,5 sampai dengan $79,5 \mathrm{~cm}(\mathrm{TL}) ; 3$ ) ikan cucut (Squalops megalops) memiliki kisaran antara 41,5 sampai dengan 70,5 cm (FL); dan 4) Chlorophtalmus nigromarginatus memiliki kisaran antara 13,5 sampai dengan 19,5 cm (FL). Hasil penelitian di perairan Kai, Tanimbar, dan Laut Timor juga telah menemukan panjang total ikan mata hijau (Chlorophtalmus nigromarginatus) berkisar antara 10,5 sampai dengan $25,0 \mathrm{~cm}$ (Rustam et al., 1993). Di perairan barat 
Sumatera ditemukan panjang ikan demersal laut dalam yang dominan tertangkap berkisar antara 32,5 sampai dengan 70,5 cm (TL) untuk ikan Lamprogrammus niger (ashiro), antara 12,5 sampai dengan 32,5 (TL) bagi ikan Hoplosthethus sp., antara 13,5 sampai dengan 23,5 cm (FL) untuk ikan Diretmoides pauciradiatus serta antara 12,5 sampai dengan 24,5 bagi ikan Beryx splendens (FL). Dari berbagai ukuran panjang ikan demersal laut dalam yang dominan tertangkap terlihat ikan demersal yang tertangkap ukuran sangat bervariasi, yang berarti populasi terdiri atas berbagai kelas umur (Sparre \& Venema, 1992).

\section{Penyebaran}

Pengamatan frekuensi kejadian tertangkap (occurrence) di perairan selatan Jawa (Tabel 1), terlihat ikan Chlorophtalmus nigromarginatus dan ikan cucut (Squalops megalops) menempati urutan tertinggi yaitu masing-masing 50\%, kemudian diikuti ikan layur ( $T$. lepturus) 33\%, serta ikan Lamprogrammusniger sp. $17 \%$. Dari fenomena ini terindikasi bahwa jenis Chlorophtalmus nigromarginatus dan ikan cucut (Squalops megalops) memiliki penyebaran yang cukup luas di perairan selatan Jawa (Gambar 3).

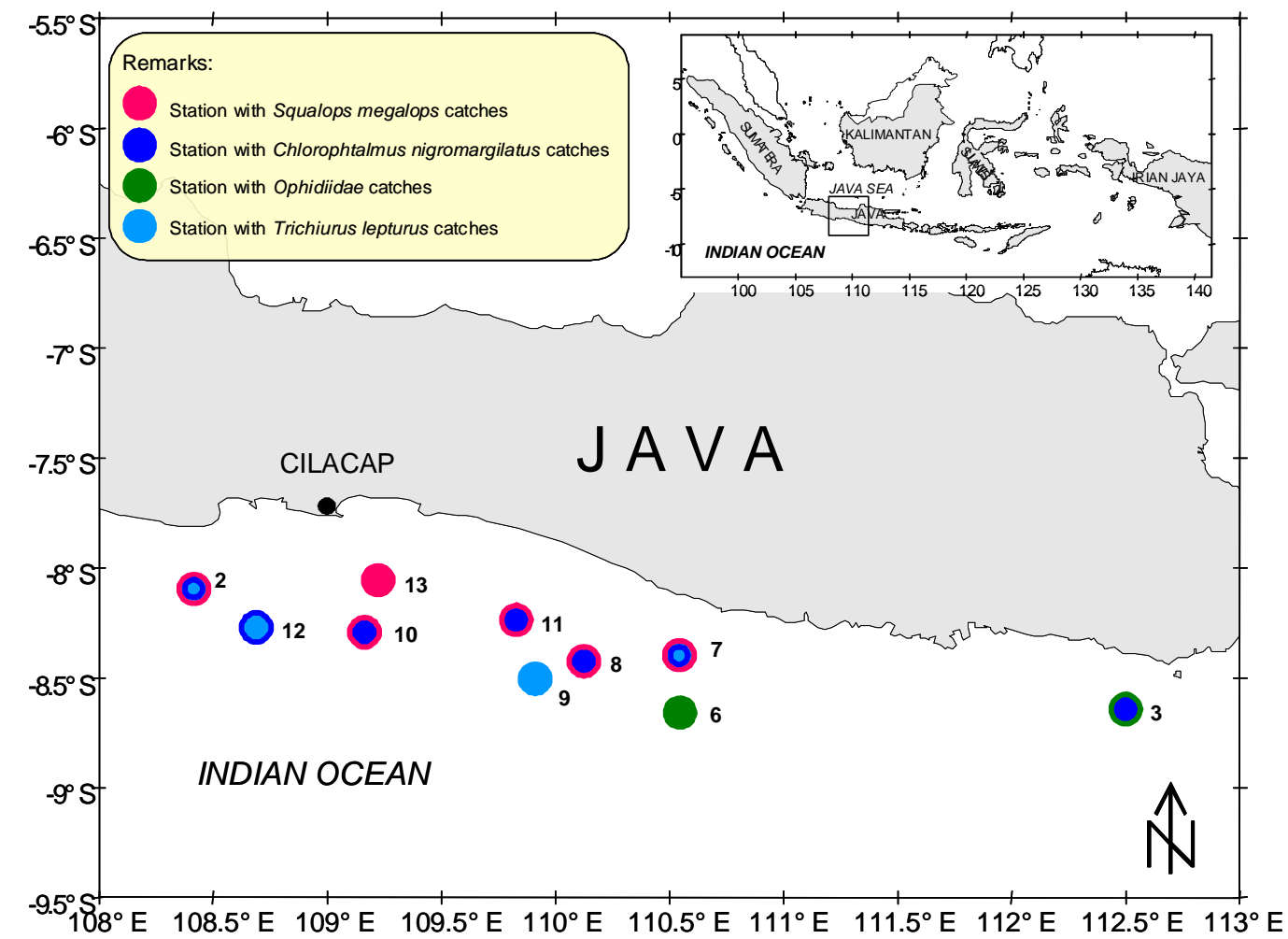

Gambar 3. Penyebaran ikan demersal laut dalam yang dominan di perairan selatan Jawa.

Figure 3. Distribution of dominan species in southern off Java waters.

Terbatas penyebaran ikan ashiro dan ikan layur nampak disebabkan penyebaran ke-2 jenis ini sangat dipengaruhi kedalaman. Ikan ashiro hanya dapat ditemui pada kedalaman lebih dari $750 \mathrm{~m}$ dan ikan layur ditemui pada kedalaman kurang dari $400 \mathrm{~m}$. Fenomena yang sama ditemukan pada penyebaran ikan ashiro di perairan Kai, Tanimbar, dan Laut Timor (Soselisa et al., 1993)

Analisis selanjutnya pada Tabel 1, terlihat di perairan barat Sumatera didapatkan frekuensi kejadian tertangkap (occurrence) ikan demersal laut dalam yang tertinggi adalah ikan Diretmoides pauciradiatus sekitar $65 \%$, selanjutnya diikuti Hoplosthethus sp. sekitar 52\%, ikan Lamprogrammusniger sp. sekitar $43 \%$, serta ikan Beryx splendens 35\%. Dari indikasi ini terlihat bahwa ikan Diretmoides pauciradiatus memiliki penyebaran paling luas di perairan barat Sumatera yaitu tertangkap mulai dari perairan barat Lampung sampai dengan perairan barat Aceh (Gambar 4). Sementara itu, ikan yang agak terbatas penyebaran (frekuensi kejadian tertangkap hanya $43 \%$ ) adalah ikan Beryx splendens yang hanya ditemui pada stasiun penangkapan di dekat Pulau Enggano dan Pulau Simeulu (Gambar 4). Diduga penyebaran ikan ini ada kaitan dengan kesukaan pada habitat gunung-gunung di bawah laut (Nakabo, 2002), yang di perairan barat Sumatera banyak terdapat di sekitar 2 gugusan pulau-pulau tersebut.(Wudianto \& Satria, 2007). 


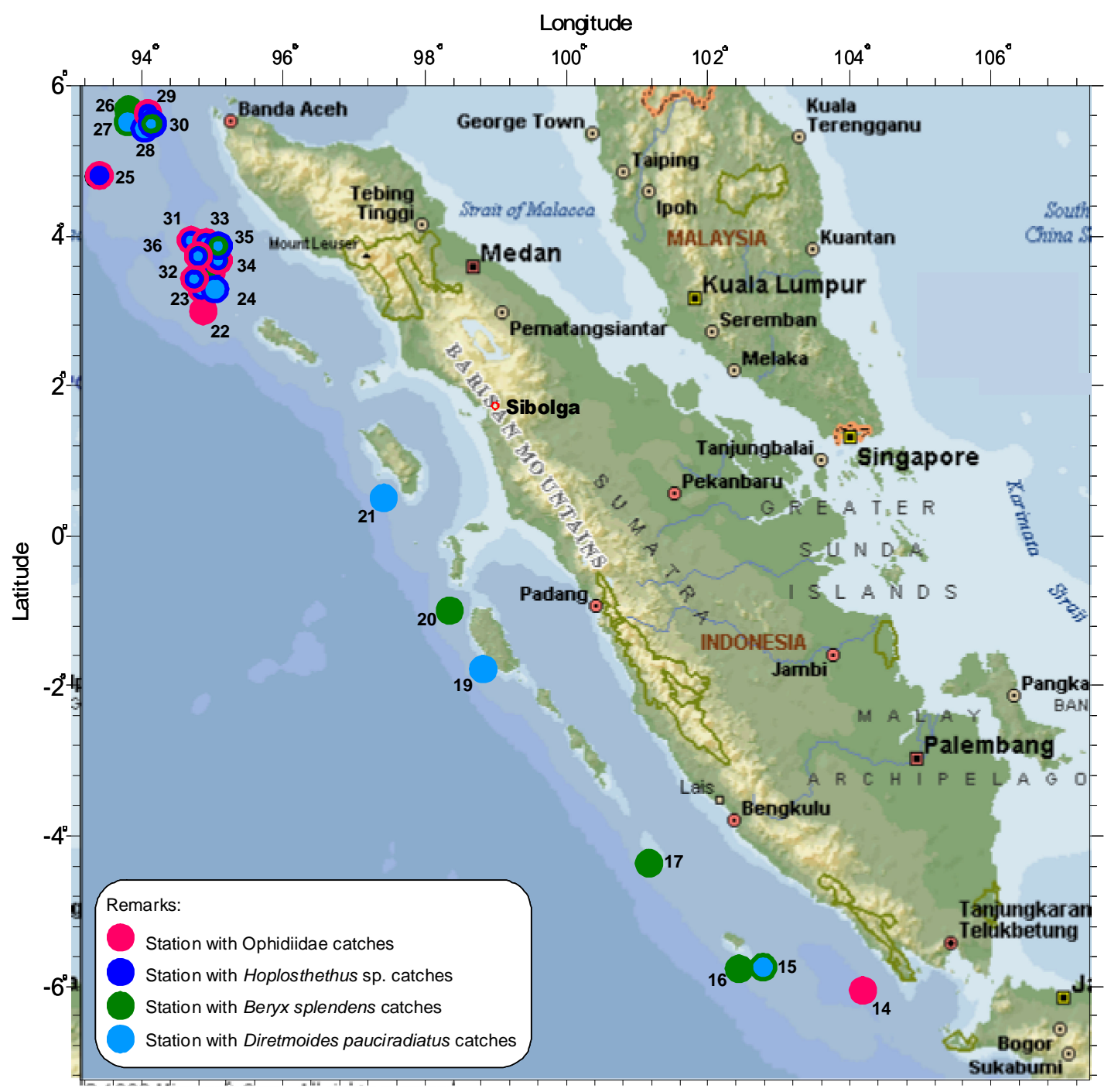

Gambar 4. Penyebaran ikan demersal laut dalam yang dominan di perairan barat Sumatera.

Figure 4. Distribution of dominant species in western off Sumatera waters.

Berdasarkan pada strata kedalaman nampak ikan demersal laut dalam menyebar pada kisaran kedalaman 200 sampai dengan $1.100 \mathrm{~m}$. Analisis lebih lanjut tentang penyebaran menurut strata kedalaman, terlihat ikan demersal laut dalam di perairan selatan Jawa dan barat Sumatera lebih tinggi pada kedalaman 700 sampai dengan $1.100 \mathrm{~m}$ dan yang terendah pada kedalaman 200 sampai dengan 400 m (Gambar 5). Hal ini, diduga terkait dengan habitat ikan demersal laut dalam yang pada umumnya lebih banyak menyukai perairan yang lebih dalam, hanya beberapa jenis tertentu seperti ikan layur ( $T$. lepturus) yang memiliki toleransi untuk hidup di perairan yang lebih dangkal. Hasil penelitian di perairan Kai, Tanimbar, dan Laut Timor menemukan penyebaran ikan demersal laut dalam tertinggi terdapat pada kedalaman $1.000 \mathrm{~m}$ (Soselisa et al., 1993), sementara di perairan selatan Jawa ditemukan pada kedalaman 400 sampai dengan $900 \mathrm{~m}$ (Sondita et al., 2004). 


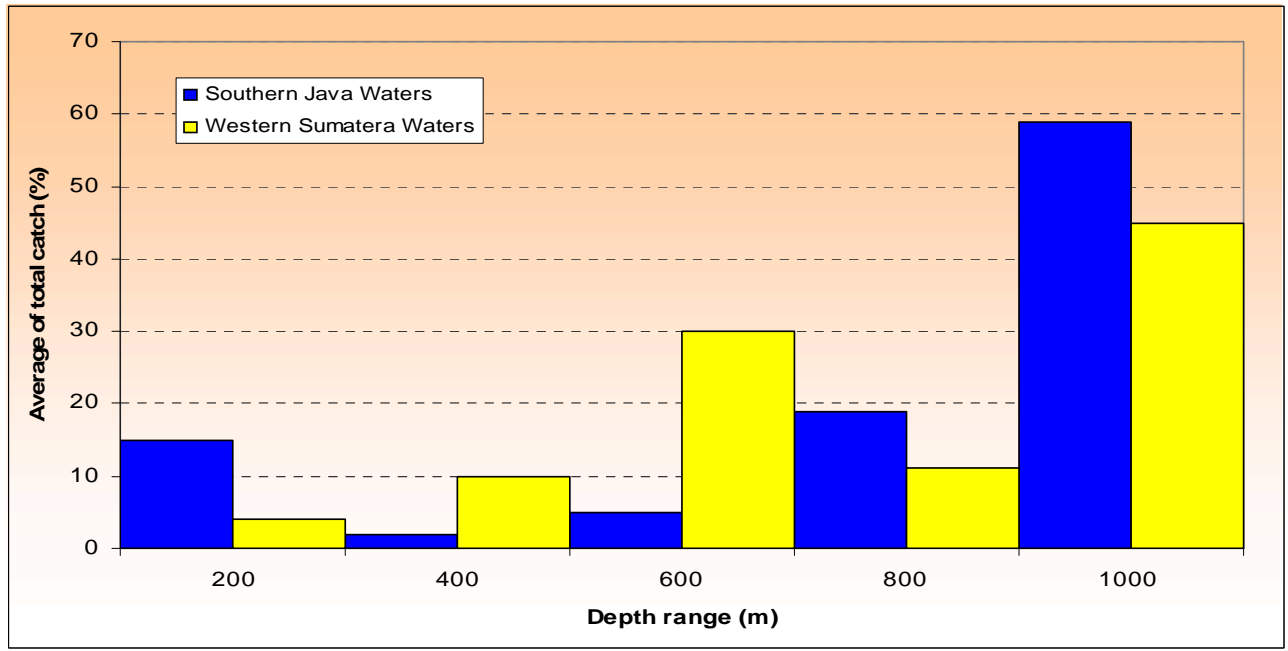

Gambar 5. Penyebaran ikan demersal laut dalam di perairan selatan Jawa dan barat Sumatera menurut kedalaman perairan.

Figure 5. Distribution of deep sea demersal fish in the south off Java and west off Sumatera waters according to water depth.

\section{Kepadatan Stok}

Dari 36 stasiun pengambilan contoh penangkapan ikan demersal laut dalam yang dilakukan di perairan selatan Jawa dan barat Sumatera didapatkan kepadatan stok ikan demersal laut dalam seperti tersaji pada Tabel 2.

Dari Tabel 2 menunjukkan bahwa kepadatan stok ikan demersal laut dalam di perairan selatan Jawa berkisar antara 0,8 sampai dengan 39,9 ton $\mathrm{km}^{-2}$. Stasiun yang paling rendah kepadatan stok adalah stasiun 10 yang terdapat di sebelah selatan Cilacap dan yang tertinggi pada stasiun 4 di sebelah selatan Yogyakarta. Secara spasial, terlihat kepadatan stok lebih tinggi di perairan bagian barat yaitu di sekitar perairan selatan Jawa Tengah, bila dibandingkan di bagian barat yang meliputi wilayah perairan selatan Jawa Timur (Gambar $6)$.

Tabel 2. Kepadatan stok ikan demersal laut dalam di perairan Samudera Hindia sebelah selatan Jawa dan barat Sumatera

Table 2. Stock density of deep sea demersal fish in Indian Ocean at south off Java and west off Sumatera waters

\begin{tabular}{|c|c|c|c|c|c|}
\hline Lokasi/Location & Stasiun/Station & CPUA (kg km-2) & Lokasi/Location & Stasiun/Station & CPUA (kg km-2) \\
\hline Southern Java & 1 & 0 (unsuccessful) & Western Sumatera & 14 & 7.395 \\
\hline \multirow[t]{22}{*}{ Waters } & 2 & 6.936 & Waters & 15 & 4.020 \\
\hline & 3 & 2.360 & & 16 & 899 \\
\hline & 4 & 39.863 & & 17 & 365 \\
\hline & 5 & 3.143 & & 18 & 291 \\
\hline & 6 & 18.565 & & 24 & 835 \\
\hline & 7 & 8.173 & & 25 & 367 \\
\hline & 8 & 1.007 & & 26 & 453 \\
\hline & 9 & 987 & & 27 & 223 \\
\hline & 10 & 794 & & 28 & 1.911 \\
\hline & 11 & 4.802 & & 29 & 582 \\
\hline & 12 & 22.816 & & 30 & 2.389 \\
\hline & 13 & 5.915 & & 31 & 821 \\
\hline & & & & 32 & 536 \\
\hline & & & & 33 & 6.242 \\
\hline & & & & 34 & 453 \\
\hline & & & & 35 & 846 \\
\hline & & & & 36 & 735 \\
\hline & & & & 19 & 259 \\
\hline & & & & 20 & 470 \\
\hline & & & & 21 & 423 \\
\hline & & & & 22 & 275 \\
\hline & & & & 23 & 342 \\
\hline
\end{tabular}




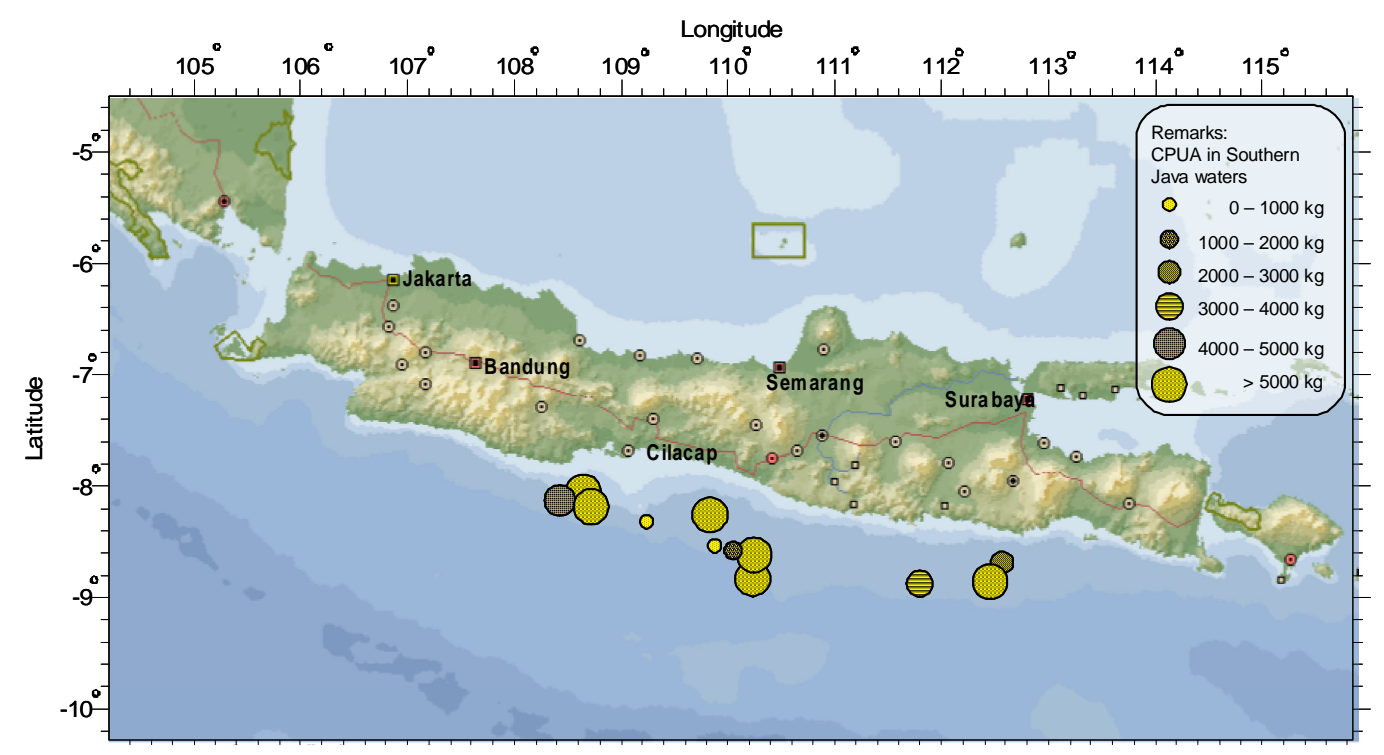

Gambar 6. Figure 6.

Kepadatan stok ikan demersal laut dalam di perairan selatan Jawa. Stock density of deep sea demersal fishes in southern off Java waters.

Selanjutnya, pada Tabel 2 terlihat bahwa kepadatan stok ikan demersal laut dalam di perairan barat Sumatera berkisar antara 0,2 ton $\mathrm{km}^{-2}$ (stasiun 22) sampai dengan 7,4 ton $\mathrm{km}^{-2}$ (stasiun 14). Stasiun yang paling rendah kepadatan stok terdapat di sebelah barat Pulau Simeulu dan yang tertinggi di sebelah barat
Lampung. Secara spasial, terlihat kepadatan stok lebih tinggi di perairan bagian paling barat (sebelah barat Pulau Weh) dan paling timur (sebelah barat Lampung), bila dibandingkan di bagian tengah yang meliputi wilayah perairan barat Enggano, Mentawai, Nias, dan Simeulu (Gambar 7).

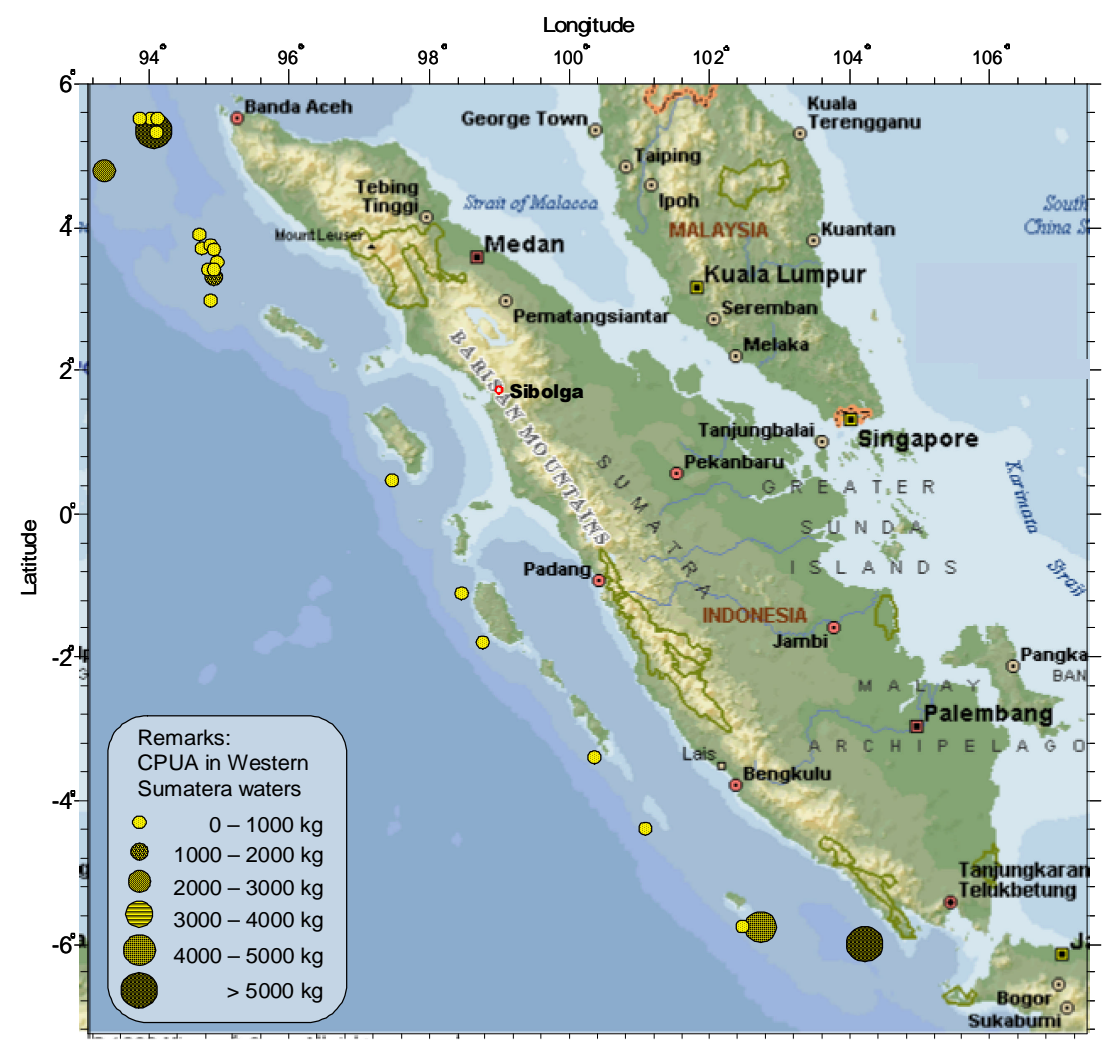

Gambar 7.

Kepadatan stok ikan demersal laut dalam di perairan barat Sumatera.

Figure 7. Stock density of deep sea demersal fishes in west off Sumatera waters. 
Analisis lebih lanjut menunjukkan kepadatan stok ikan demersal laut dalam di perairan selatan Jawa lebih tinggi bila dibandingkan dengan kepadatan stok ikan demersal laut dalam di perairan barat Sumatera. Tetapi apabila dilihat jenis-jenis ikan, terlihat di perairan barat Sumatera ditemui lebih banyak ikan ekonomis penting dibanding perairan selatan Jawa. Secara umum, kepadatan stok ikan demersal laut dalam di perairan selatan Jawa dan barat Sumatera adalah lebih tinggi bila dibandingkan dengan kepadatan stok ikan demersal laut dalam di perairan Kai, Tanimbar, dan Laut Timor yang berkisar 72 sampai dengan $294 \mathrm{~kg} \mathrm{~km}^{-2}$ (Soselisa et al., 1993).

\section{KESIMPULAN}

1. Komposisi jenis ikan demersal laut dalam yang tertangkap di perairan barat Sumatera lebih tinggi bila dibandingkan dengan perairan selatan Jawa dan spesies yang mendominasi untuk ke-2 wilayah perairan tersebut adalah ikan Ashiro (Lamprogrammus niger). Jenis ikan demersal laut dalam yang memiliki penyebaran yang paling luas di perairan selatan Jawa adalah ikan Chlorophtalmus nigromarginatus dan di perairan barat Sumatera adalah ikan Diretmoides pauciradiatus.

2. Daerah penyebaran ikan demersal laut dalam di perairan selatan Jawa dan barat Sumatera terdapat pada kedalaman antara 200 sampai dengan 1.100 $\mathrm{m}$ dan penyebaran ikan tersebut lebih tinggi pada kedalaman antara 700 sampai dengan $1.100 \mathrm{~m}$.

3. Kepadatan stok ikan demersal laut dalam di perairan selatan Jawa berkisar antara 0,8 sampai dengan 39,9 ton per $\mathrm{km}^{-2}$ dan di perairan barat Sumatera berkisar antara 0,2 sampai dengan 7,4 ton per $\mathrm{km}^{-2}$, sementara kepadatan stok tertinggi di perairan selatan Jawa ditemukan di sekitar selatan Jawa Tengah dan di perairan barat Sumatera didapatkan di sekitar barat Lampung.

\footnotetext{
$\overline{\text { Persantunan }}$

Hasil dari kegiatan riset: The Japan-Indonesia Deep Sea Fisheries Resources Joint Exploration Marine Resources T.A. 2004 di Overseas Fishery Coorperation Foundation
}

\section{DAFTAR PUSTAKA}

Anonimus. 1972. Survei Samudera Indonesia (tanggal 12 Nopember sampai dengan 1 Desember, 1972). Laporan Penelitian Perikanan Laut No.1/1972. 2758.

Anonimus. 2005. Forum pengkajian stok sumber daya ikan laut. Pusat Riset Perikanan Tangkap. Badan Riset Kelautan dan Perikanan. Departemen Kelautan dan Perikanan.

Anonymous. 2005a. The Japan-Indonesia deep sea fishery resources joint exploration project (Report of 2004 field survey). Overseas Fishery Cooperation Foundation-Research Institute for Marine Fisheries.

Anonymous. 2006. The Japan-Indonesia deep sea fishery resources joint exploration project (Final report). Overseas Fishery Cooperation FoundationAgency of Marine and Fisheries Research.

Carpenter, K. E. \& V. H. Niem (eds.). 1998. FAO identification guide for fishing purpose. The Living Marine Resources of the Western Central Pacific. Vol.2. Chepalopods, Crustaceans, Holothurians, and Sharks. FAO Rome.

Dall, W., B. J. Hill, P. C. Rothlisberg, \& D. J. Staples. 1990. The biology of the Penaeidae. In Blaxter, J. H. S. \& A. J. Southward (eds.). Marine Biology. Vol.27. Academic Press. London, San Diego, New York, Boston, Sydney, Tokyo, and Toronto. 489 p.

George, M. J. 1967. On a collection of penaeid prawns from the offshore water of the south-west India. In Proceeding of symposium on crustacea. Part 1. $\mathrm{p}$ 337-344.

Holthuis, L. B. 1991. FAO species catalogue. Vol.13. Marine lobsters of the world. An annotated and illustrated catalogue of species interest to fisheries know to date. FAO Fish. Synop. (125) Vol.13: 292 p.

King, M. J. 1986. Deep water shrimps. The fishery resources of Pacific Island countries. Part I FAO Fish. Tech. Pap. (272.1): 45 p. 
Naamin, N. 1987. Perikanan laut di Indonesia: Prospek dan problema pengembangan sumber daya perikanan laut. Makalah disampaikan pada Seminar Laut Nasional II. Jakarta. 26 hal.

Nakabo, T. 2002. Fishes of Japan with pectorial keys to the species. Tokai University Press. Book I. 866 p Book II. 867-1748.

Rustam, R., J. Soselisa, \& Badrudin. 1993. Hubungan panjang berat, nisbah kelamin, dan tingkat kematangan ovarium ikan mata hijau (Chloropthalmus nigromarginatus) di perairan Kai, Tanimbar, dan Laut Timor. Jurnal Penelitian Perikanan Laut. No.77. 33-41.

Saeger, J., P. Martosubroto, \& D. Pauly. 1976. Fish report of the Indonesia German demersal fisheries project. Result of a trawl survey in the Sunda Shelf area. Laporan Penelitian Perikanan Laut. No.1. 1-46.

Shindo, S. 1973. General review of the trawl fisheries and the demersal fish stock of the South China Sea. FAO Fish. Tech. Pap. No.120. FAO. Rome.
Sondita, M. F. A., Sulistiono, A. Purbayanto, Sudirman, F. Satria, \& M. A. Sofijanto. 2004. Demersal fisheries resources in Indian Ocean off southern coast of Java and Bali. Lokakarya Hasil Survei Traw/Sumber Daya Ikan Laut Dalam di Samudera Hindia. Fakultas Perikanan dan IImu Kelautan. Institut Pertanian Bogor. Bogor. P II-1-II-16.

Soselisa, J., R. Rustam, \& M. Badrudin. 1993. Penyebaran dan potensi sumber daya ikan demersal laut dalam di perairan Kai, Tanimbar, dan Laut Timor. Jurnal Penelitian Perikanan Laut. No.77. 27-32.

Sparre, P. \& S. C. Venema. 1992. Introduction to tropical fish stock assesment. Part I. Manual. FAO Fish Tech. Pap. No.306/1.

Wudianto \& F. Satria. 2007. Identification of fishing ground for deep sea demersal fish and it's possibility for fishing development in the Indian Ocean Pusat Riset Perikanan Tangkap. Jakarta (dalam proses diterbitkan). 